\title{
Synthesis of Fe-Li-Cr Multinuclear Complexes as Molecular Magnet Materials
}

\author{
Djulia Onggo, Iis Siti Jahro, Fahimah Martak \& Ismunandar \\ Inorganic and Physical Chemistry Group, Faculty of Mathematics and Natural Sciences \\ Institut Teknologi Bandung, Jalan Ganesha 10 Bandung 40132, Indonesia \\ Email: djulia@chem.itb.ac.id
}

\begin{abstract}
Multinuclear complexes have received considerable interest as molecular magnet materials. Up to now, several complex compounds based on bidentate ligand 2,2' bipyridine have been synthesized. In this research, the FeLi-Cr multinuclear complexes with derivative 2'2- bipyridine ligands: 2-(2'pyridyl)quinoline(pq), 2,2'-Pyridil(pdl) have been synthesized. The oxalate (ox) ligand has also been used as a bridging ligand in these multinuclear complexes. The chemical formula of $\mathrm{Li}\left[\mathrm{FeCr}(\mathrm{ox})_{2}(\mathrm{pq})\left(\mathrm{BF}_{4}\right)_{2}\left(\mathrm{H}_{2} \mathrm{O}\right)_{2}\right]$ and $\left[\mathrm{Fe}(\mathrm{pdl})_{\mathrm{n}}\right]\left[\mathrm{LiCr}(\mathrm{ox})_{3}\right]$ complexes have been verified using metal and $\mathrm{C}, \mathrm{H}, \mathrm{N}$ elemental analysis data. The IR spectra in $350-4000 \mathrm{~cm}^{-1}$ range exhibit characteristic absorptions, which support the proposed structure of complex. The plausible structure of the compounds has been drawn based on complex formation mechanism. The magnetic susceptibility at room temperature of the pq-complex is about 5.7 BM and of the pdl- complexes are 4.8 and 5.5 BM. These indicated that both spin states of iron(II) exist in the multinuclear complexes.
\end{abstract}

Keywords: 2-(2'-pyridyl)quinoline(pq); 2,2'-pyridil(pdl); $\mathrm{Fe}-\mathrm{Li}$-Cr multinuclear complexes; oxalate(ox) ligands.

\section{Introduction}

Molecular magnet materials are chemical compounds which able to show magnetic properties on molecular scale. The magnetic behaviour of such compounds is based on a microstructure of active materials. For example, iron(II) complexes can be either paramagnetic or diamagnetic depending on their electronic spin state which is influenced by the ligand field strength [1], [2]. When strong field ligands such as 2,2'-bipyridine(bpy), are coordinated to iron(II) the six d-electrons of the metal ion are all paired, and a diamagnetic compound results. In contrast, for weak field ligands the electrons are unpaired and paramagnetic properties are observed. The 2,2'-bipyridine derivatives like 2,(2'-pyridin-2-yl)quinoline(pq) and 2,2'-pyridil( $p d l)$ have an intermediate ligand field strength, and will be good candidates for coordinating with iron(II) to form bistable complexes which are sensitive to external effects such as temperature, pressure or light irradiation. 
Attempts have been considered in order to obtain complexes with such properties, one of them is to synthesize multinuclear complexes with polymeric structures [3, 4]. The more transition metal ions with various oxidation states involved in the multinuclear complexes, the higher their magnetic response should be. This has the potential to lead to the wider applications of the magnetic molecular systems.

The multinuclear complexes can be synthesized using bridging ligands such as the oxalate anion. The oxalate ion can act as mediator for magnetic exchange interactions between the transition-metal centers, because the oxalate structure can form multidimensional networks.

The series of oxalate polymeric compounds have been reported [5]. The $\{[\mathrm{N}(\mathrm{n}-$ $\left.\left.\left.\mathrm{C}_{4} \mathrm{H}_{9}\right)_{4}\right]\left[\mathrm{M}(\mathrm{II}) \mathrm{Cr}(\mathrm{ox})_{3}\right]\right\}_{\mathrm{n}}$ compounds, where $\mathrm{M}(\mathrm{II})=\mathrm{Mn}, \mathrm{Fe}, \mathrm{Co}, \mathrm{Ni}, \mathrm{Cu}$, show ferromagnetic phase transitions at temperatures below $15 \mathrm{~K}$. On the contrary, the $\left\{\left[\mathrm{N}\left(\mathrm{n}-\mathrm{C}_{4} \mathrm{H}_{9}\right)_{4}\right]\left[\mathrm{M}(\mathrm{II}) \mathrm{Fe}(\mathrm{ox})_{3}\right]\right\}_{\mathrm{n}}$ compounds, where $\mathrm{M}(\mathrm{II})=\mathrm{Fe}$, Ni show ferrimagnetism at temperatures below $43 \mathrm{~K}$ and $28 \mathrm{~K}$, respectively. Moreover, a further type with a mixed-valences network, $\left\{\left[\mathrm{N}\left(\mathrm{n}-\mathrm{C}_{4} \mathrm{H}_{9}\right)_{4}\right]\left[\mathrm{Cr}(\mathrm{II}) \mathrm{Cr}(\mathrm{ox})_{3}\right]\right\}_{\mathrm{n}}$, shows short-range anti-ferromagnetic correlations above the experimental temperature limit of $2 \mathrm{~K}$ [5].

Recently, Sieber, et al. [6], found that the $\left[\mathrm{Co}(b p y)_{3}\right]^{2+}$ complex is in the usual high-spin ground state, and upon incorporating this complex into the $\left[\mathrm{LiCr}(\mathrm{ox})_{3}\right]_{\mathrm{n}}^{-2 \mathrm{n}}$ network to form $\left\{\left[\mathrm{Co}(\text { bpy })_{3}\right]\left[\mathrm{LiCr}(\mathrm{ox})_{3}\right]\right\}_{\mathrm{n}}$ this becomes a spin crossover system.

In this paper, the multinuclear Fe-Li-Cr complexes have been investigated using derivative ligands of 2,2' bipyridine, namely $p q$ and $p d l$ that are coordinated to iron(II) in combination with the $\left[\mathrm{LiCr}(\mathrm{ox})_{3}\right]_{n}^{-2 n}$ network in order to develop novel magnetic behavior.

\section{Experimental Section}

The research involved preliminary work on solubility of raw materials, study mechanism of the complex formation in solution, synthesis and characterization of the multinuclear compounds.

\section{$2.1 \quad$ Materials}

The raw chemicals: $\mathrm{Fe}\left(\mathrm{BF}_{4}\right)_{2} \cdot 6 \mathrm{H}_{2} \mathrm{O}, \quad \mathrm{Fe}\left(\mathrm{ClO}_{4}\right)_{2} \cdot 6 \mathrm{H}_{2} \mathrm{O}, \quad \mathrm{LiClO}_{4} \cdot 3 \mathrm{H}_{2} \mathrm{O}$, $\mathrm{C}_{12} \mathrm{H}_{8} \mathrm{~N}_{2} \mathrm{O}_{2}(p d l)$, methanol and ethanol were used as obtained without further purification. The $\mathrm{C}_{14} \mathrm{H}_{10} \mathrm{~N}_{2}(p q)$ and $\mathrm{K}_{3}\left[\mathrm{Cr}\left(\mathrm{C}_{2} \mathrm{O}_{4}\right)_{3}\right] \cdot 3 \mathrm{H}_{2} \mathrm{O}$ have been prepared based on published paper $[7,8]$. 


\subsection{Instruments}

The instruments used are Atomic Absorption Spectroscopy (AAS) Shimadzu AA8801S, infrared spectroscopy Shimadzu FTIR-8400 and Magnetic Susceptibility Balance Sherwood scientific Ltd. The C, H, N, elemental analyses have been done in UKM (University Kebangsaan Malaysia).

\subsection{Synthesis of Fe-Li-Cr Complex}

A solution of pq (0.73g) in methanol was added to a solution of $\mathrm{Fe}\left(\mathrm{BF}_{4}\right)_{2} \cdot 6 \mathrm{H}_{2} \mathrm{O}$ $(0.34 \mathrm{~g})$ in methanol. The resulting red solution was added in a mixed solution of $\mathrm{K}_{3}\left[\mathrm{Cr}\left(\mathrm{C}_{2} \mathrm{O}_{4}\right)_{3}\right] \cdot 3 \mathrm{H}_{2} \mathrm{O}$ (0.49g) and $\mathrm{LiClO}_{4} \cdot 3 \mathrm{H}_{2} \mathrm{O}$ (0.16g). The red-purplish precipitate was separated by filtration and dried over $\mathrm{P}_{2} \mathrm{O}_{5}$.

A similar procedure was used to synthesize the $p d l$ complex. To an ethanol solution of $\mathrm{Fe}\left(\mathrm{ClO}_{4}\right)_{2} \cdot 6 \mathrm{H}_{2} \mathrm{O}(0.34$ gram $)$ was added a solution of $p d l$ ( 0.42 gram) also in ethanol. The brown solution obtained was stirred at room temperature for 30 min. Meanwhile, an aqueous solution of $\mathrm{K}_{3}\left[\mathrm{Cr}\left(\mathrm{C}_{2} \mathrm{O}_{4}\right)_{3}\right] \cdot 3 \mathrm{H}_{2} \mathrm{O}(0.46$ gram) was mixed with $\mathrm{LiClO}_{4} \cdot 3 \mathrm{H}_{2} \mathrm{O}(0.11$ gram $)$, the dark violet solution was obtained and white precipitate was immediately discard. This solution was added to the pdl solution of Fe(II). After stirring for about half an hour, a brown precipitate formed. This product was filtered off and washed with methanol and dried over $\mathrm{P}_{2} \mathrm{O}_{5}$. However, when the lithium salt was introduced in the last step, a dark brown product was obtained. This was filtered off, washed with ethanol and dried over $\mathrm{P}_{2} \mathrm{O}_{5}$.

\section{$3 \quad$ Result and Discussion}

\subsection{The Mechanism of Multinuclear Complex Formation}

The mechanism of multinuclear $p q$ complex formation could be followed by UV-Vis spectroscopy. The red $\left[\mathrm{Fe}(p q)_{3}\right]^{2+}$ complex shows a broad peak centered at $500 \mathrm{~nm}$, whereas the violet $\left[\mathrm{Cr}(\mathrm{ox})_{3}\right]^{3-}$ complex shows two different peaks at 420 and $580 \mathrm{~nm}$. The mixture of both complexes produced a new multinuclear complex which shows a single peak at $560 \mathrm{~nm}$. This indicated that the multinuclear Fe-Li-Cr complex is formed directly from the combination of the two compounds.

The mechanism of multinuclear $p d l$ complex formation is similar to the $p q$ complex, instead of the maximum peaks observed are slightly different. The yellow solution of $\left[\mathrm{Fe}(p d l)_{2}\right]^{2+}$ complex shows a broad peak centered at $390 \mathrm{~nm}$ when the ratio between iron(II) ion and $p d l$ ligand is $1: 2$. The addition of the $\left[\mathrm{LiCr}(\mathrm{ox})_{3}\right]^{2-}$ complex results in one new peak at $410 \mathrm{~nm}$, and the ratio of both complexes is $1: 1$. 
From that study, the mechanism of the multinuclear complex formation could be followed by the reactions:

$$
\begin{aligned}
& \mathrm{Fe}^{2+}+\text { ligand } \rightarrow \quad\left[\mathrm{Fe}(\text { ligand })_{\mathbf{x}}\right]^{2+} \\
& {\left[\mathrm{Cr}\left(\mathrm{C}_{2} \mathrm{O}_{4}\right)_{3}\right]^{3-}+\mathrm{Li}^{+} \rightarrow \underset{\left.\mathrm{LiCr}\left(\mathrm{C}_{2} \mathrm{O}_{4}\right)_{3}\right]^{2-}}{\rightarrow} \rightarrow\left[\mathrm{Fe}(\text { ligan })_{3}\right]^{2+}+\left[\mathrm{LiCr}\left(\mathrm{C}_{2} \mathrm{O}_{4}\right)_{3}\right]^{2-} \rightarrow\left[\mathrm{Fe}(\text { ligan })_{\mathbf{x}}\right]\left[\operatorname{LiCr}\left(\mathrm{C}_{2} \mathrm{O}_{4}\right)_{3}\right]}
\end{aligned}
$$

\subsection{Synthesis and Structure}

It was possible to synthesize only one $\mathrm{Fe}-\mathrm{Li}-\mathrm{Cr}$ multinuclear $p q$ complex, the chemical formula of this being $[\mathrm{Fe}(p q)]\left[\mathrm{LiCr}\left(\mathrm{C}_{2} \mathrm{O}_{4}\right)_{2}\left(\mathrm{BF}_{4}\right)_{2} 2 \mathrm{H}_{2} \mathrm{O}\right.$. This compound has red purplish colour, is poorly soluble in water or organic solvents such acetone, diethyl ether, methanol, ethanol, acetonitrille, DMF and DMSO.

Two Fe-Li-Cr multinuclear complexes of $p d l$ have been obtained, the chemical formula for both compounds being $[\mathrm{Fe}(p d l)]\left[\mathrm{LiCr}\left(\mathrm{C}_{2} \mathrm{O}_{4}\right)_{3}\right]$ and $\left[\mathrm{Fe}(p d l)_{2}\right]\left[\mathrm{LiCr}\left(\mathrm{C}_{2} \mathrm{O}_{4}\right)_{3}\right]$. The latter compound was obtained when the lithium salt was added at the final step. The metal ion contents and the $\mathrm{C}, \mathrm{H}, \mathrm{N}$ elemental data for all complexes are listed in Table 1.

Table 1 The metal ion contents and elemental data of multinuclear complexes.

\begin{tabular}{lccccc}
\hline Compounds & $\mathbf{F e}$ & $\mathbf{C r}$ & $\mathbf{C}$ & $\mathbf{H}$ & $\mathbf{N}$ \\
\hline$[\mathrm{Fe}(p q)]\left[\mathrm{LiCr}\left(\mathrm{C}_{2} \mathrm{O}_{4}\right)_{2}\left(\mathrm{BF}_{4}\right)_{2}\right.$ & 7.21 & 6.98 & 29.84 & 1.65 & 4.58 \\
$2 \mathrm{H}_{2} \mathrm{O}$ & $(7.90)$ & $(7.36)$ & $(30.59)$ & $(2.00)$ & $(3.96)$ \\
{$[\mathrm{Fe}(p d l)]\left[\mathrm{LiCr}\left(\mathrm{C}_{2} \mathrm{O}_{4}\right)_{3}\right]$} & 9.67 & 8.94 & 36.26 & 1.47 & 4.39 \\
& $(9.47)$ & $(8.79)$ & $(36.42)$ & $(1.69)$ & $(4.72)$ \\
{$\left[\mathrm{Fe}(p d l)_{2}\right]\left[\mathrm{LiCr}\left(\mathrm{C}_{2} \mathrm{O}_{4}\right)_{3}\right]$} & 7.10 & 6.59 & 44.25 & 1.87 & 6.82 \\
& $(6.97)$ & $(6.47)$ & $(44.83)$ & $(1.99)$ & $(6.97)$ \\
\hline
\end{tabular}

(..) = calculated.

In order to clarify the mode of bonding, the Infra Red (IR) spectra of these complexes were recorded. The following discussion is confined to the most important vibrations in $350-4000 \mathrm{~cm}^{-1}$ region. In the IR spectra, the characteristic absorptions of oxalato-bridged group, the ligands, $\mathrm{N}-\mathrm{M}-\mathrm{N}$ bonding $(\mathrm{M}=\mathrm{Fe})$ and $\mathrm{O}-\mathrm{M}-\mathrm{O}$ bonding $(\mathrm{M}=\mathrm{Cr})$ were observed. For the oxalate ligand, the strong $v_{\text {as }} \mathrm{O}-\mathrm{C}$ band at $1678 \mathrm{~cm}^{-1}$, a weak $v_{\mathrm{s}} \mathrm{O}-\mathrm{C}$ doublet in the $1450-1350 \mathrm{~cm}^{-1}$ range and a sharp $\delta \mathrm{O}-\mathrm{C}$ band at $812 \mathrm{~cm}^{-1}$ are observedd. For the 2-(2'-pyridyl)quinoline ligand, a broad band in the range $3100-3700 \mathrm{~cm}^{-1}$ characteristic of $=\mathrm{C}-\mathrm{H}$ aromatic ring is observed and the peaks in the range $440-490 \mathrm{~cm}^{-1}$ correspond to $\mathrm{N}-\mathrm{M}-\mathrm{N}(\mathrm{M}=\mathrm{Fe})$ bonding bands. The wide band at $3400 \mathrm{~cm}^{-1}$ suggested that the water molecule exist in the multinuclear complex. The IR spectrum of multinuclear $[\mathrm{Fe}(p q)]\left[\mathrm{LiCr}\left(\mathrm{C}_{2} \mathrm{O}_{4}\right)_{2}\left(\mathrm{BF}_{4}\right)_{2}\right] 2 \mathrm{H}_{2} \mathrm{O}$ complex is shown in Figure 1. 


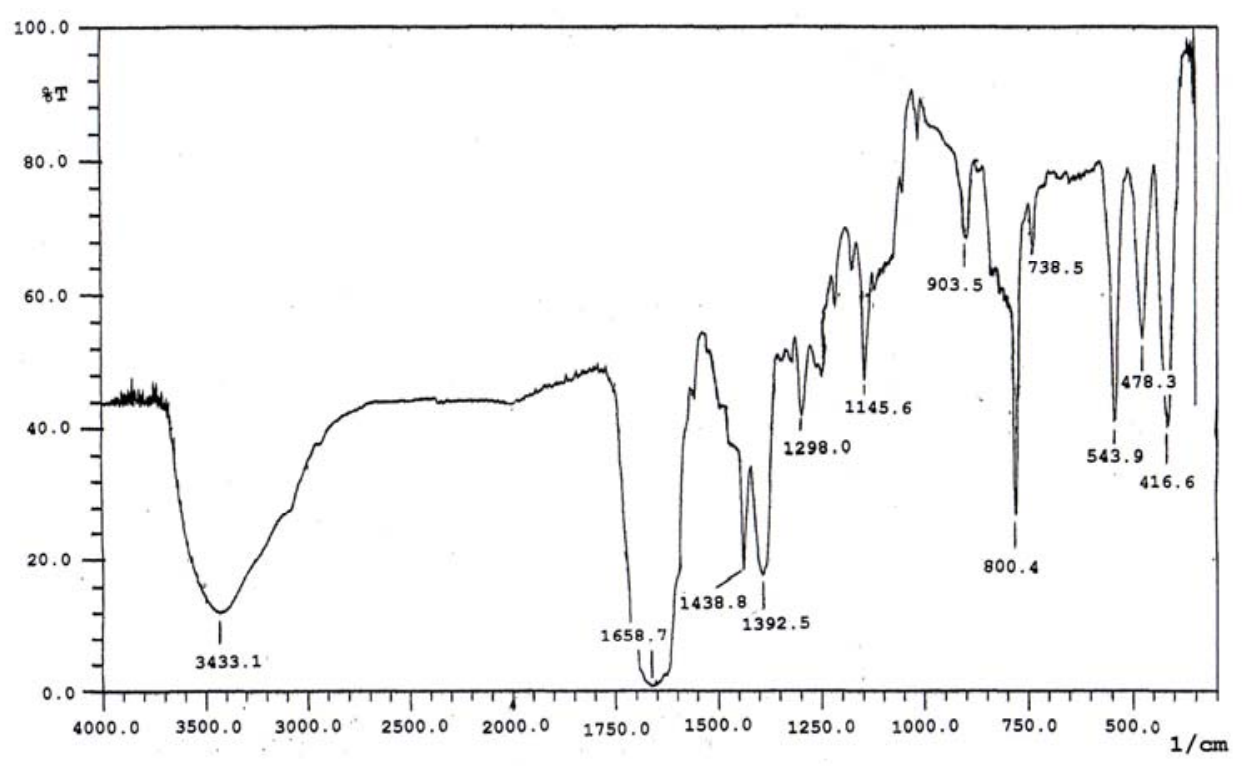

Figure 1 The IR spectra of $[\mathrm{Fe}(p q)]\left[\mathrm{LiCr}\left(\mathrm{C}_{2} \mathrm{O}_{4}\right)_{2}\left(\mathrm{BF}_{4}\right)_{2}\right] 2 \mathrm{H}_{2} \mathrm{O}$

The most relevant IR absorption bands of the complex, together with their assignments are given in Table 2.

Table 2 The most relevant IR absorption bands and their assignment.

\begin{tabular}{cc}
\hline $\mathbf{1} / \boldsymbol{\lambda}\left(\mathbf{C m}^{-\mathbf{1}}\right)$ & The assignment \\
\hline 416.6 & $\mathrm{O}-\mathrm{M}-\mathrm{O} ; \mathrm{M}=\mathrm{Cr}(\mathrm{III}), \mathrm{Fe}(\mathrm{II})$ \\
478.3 & $\mathrm{~N}-\mathrm{M}-\mathrm{N} ; \mathrm{M}=\mathrm{Fe}(\mathrm{II})$ \\
$800.4 ; 1392.5 ; 1678.0$ & $\delta \mathrm{O}-\mathrm{C} ; \mathrm{v}_{\mathrm{s}} \mathrm{O}-\mathrm{C}$ and $v_{\text {as }} \mathrm{O}-\mathrm{C}$ \\
$903.5 ; 3433.1$ & $v_{\mathrm{s}}$ and $v_{\mathrm{as}}-\mathrm{C}-\mathrm{H}(=\mathrm{C}-\mathrm{H})$ \\
3433.1 & $-\mathrm{O}-\mathrm{H}$ \\
1298.0 & $-\mathrm{B}-\mathrm{F}$ \\
\hline
\end{tabular}

$\mathrm{Li}$

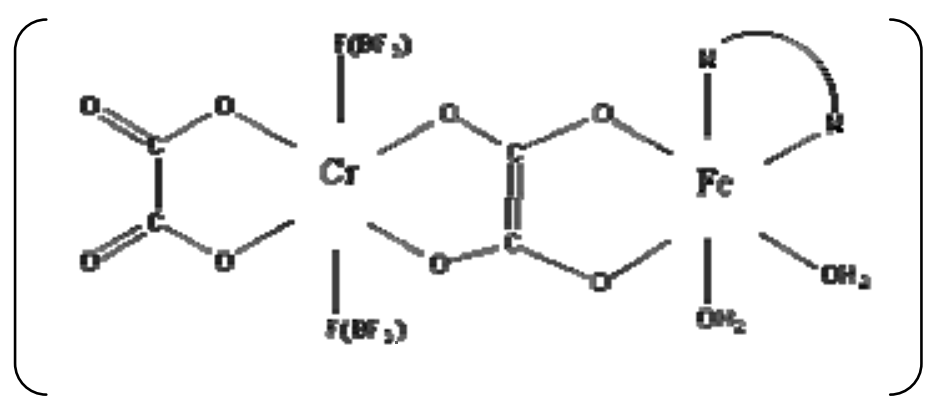

Figure 2 The plausible structure of $[\mathrm{Fe}(p q)]\left[\mathrm{LiCr}\left(\mathrm{C}_{2} \mathrm{O}_{4}\right)_{2}\left(\mathrm{BF}_{4}\right)_{2}\right] 2 \mathrm{H}_{2} \mathrm{O}$ $(\mathrm{N} \quad \mathrm{N}=p q)$. 
The plausible structure of $[\mathrm{Fe}(p q)]\left[\mathrm{LiCr}\left(\mathrm{C}_{2} \mathrm{O}_{4}\right)_{2}\left(\mathrm{BF}_{4}\right)_{2}\right] 2 \mathrm{H}_{2} \mathrm{O}$ is proposed by the following mechanism of reaction:

1. Reaction of a solution $\mathrm{Fe}\left(\mathrm{BF}_{4}\right)_{2} \cdot 6 \mathrm{H}_{2} \mathrm{O}\left(\left[\mathrm{Fe}\left(\mathrm{H}_{2} \mathrm{O}\right)_{6}\right]^{2+}\right)$ with $p q$ ligand results in substitution of two $\mathrm{H}_{2} \mathrm{O}$ by one of $p q$ ligand:

$$
\begin{aligned}
& {\left[\mathrm{Fe}\left(\mathrm{H}_{2} \mathrm{O}\right)_{6}\right]\left(\mathrm{BF}_{4}\right)_{2} \longrightarrow\left[\mathrm{Fe}\left(\mathrm{H}_{2} \mathrm{O}\right)_{6}\right]^{2+}+2 \mathrm{BF}_{4}^{-}} \\
& {\left[\mathrm{Fe}\left(\mathrm{H}_{2} \mathrm{O}\right)_{6}\right]^{2+}+\mathrm{C}_{14} \mathrm{H}_{10} \mathrm{~N}_{2}(p q) \longrightarrow\left[\mathrm{Fe}\left(\mathrm{H}_{2} \mathrm{O}\right)_{4}(p q)\right]^{2+}+2 \mathrm{H}_{2} \mathrm{O}} \\
& {\left[\mathrm{Fe}\left(\mathrm{H}_{2} \mathrm{O}\right)_{6}\right]\left(\mathrm{BF}_{4}\right)_{2}+\mathrm{C}_{14} \mathrm{H}_{10} \mathrm{~N}_{2}(p q) \longrightarrow\left[\mathrm{Fe}\left(\mathrm{H}_{2} \mathrm{O}\right)_{4}(p q)\right]^{2+}+2 \mathrm{BF}_{4}^{-}}
\end{aligned}
$$

2. Reaction of a solution which contains $\left[\mathrm{Fe}\left(\mathrm{H}_{2} \mathrm{O}\right)_{4}(p q)\right]^{2+}$ and $\mathrm{BF}_{4}^{-}$ions with a solution which contains $\left[\mathrm{Cr}\left(\mathrm{C}_{2} \mathrm{O}_{4}\right)_{3}\right]^{3-}$ and $\mathrm{Li}^{+}$caused substitution of two $\mathrm{H}_{2} \mathrm{O}$ on $\left[\mathrm{Fe}\left(\mathrm{H}_{2} \mathrm{O}\right)_{4}(p q)\right]^{2+}$ by an oxalate ion $\left(\mathrm{C}_{2} \mathrm{O}_{4}{ }^{2-}\right)$ from $\left[\mathrm{Cr}\left(\mathrm{C}_{2} \mathrm{O}_{4}\right)_{3}\right]^{3-}$. At the same time, one of the oxalate ions on $\left[\mathrm{Cr}\left(\mathrm{C}_{2} \mathrm{O}_{4}\right)_{3}\right]^{3-}$ is replaced by two $\mathrm{BF}_{4}{ }^{-}$ions and resulting in the formation of the complex $\left\{\mathrm{Li}\left[\mathrm{FeCr}\left(\mathrm{C}_{2} \mathrm{O}_{4}\right)_{2}(p q)\left(\mathrm{BF}_{4}\right)_{2}\left(\mathrm{H}_{2} \mathrm{O}\right)_{2}\right]\right\}$ which precipitated. Reaction:

$$
\begin{gathered}
{\left[\mathrm{Fe}\left(\mathrm{H}_{2} \mathrm{O}\right)_{4}(\mathrm{pq})\right]^{2+}+2 \mathrm{BF}_{4}^{-}+\left[\mathrm{Cr}\left(\mathrm{C}_{2} \mathrm{O}_{4}\right)_{3}\right]^{3-}+\mathrm{Li}^{+}} \\
\downarrow \\
{[\mathrm{Fe}(p q)]\left[\mathrm{LiCr}\left(\mathrm{C}_{2} \mathrm{O}_{4}\right)_{2}\left(\mathrm{BF}_{4}\right)_{2}\right] 2 \mathrm{H}_{2} \mathrm{O}(\mathrm{s})+\mathrm{C}_{2} \mathrm{O}_{4}{ }^{2-}+2 \mathrm{H}_{2} \mathrm{O}}
\end{gathered}
$$

The IR spectrum of $\left[\mathrm{Fe}(p d l)_{\mathrm{n}}\right]\left[\mathrm{LiCr}\left(\mathrm{C}_{2} \mathrm{O}_{4}\right)_{3}\right]$ has also been recorded. From the spectrum, the stretching vibration $\mathrm{O}-\mathrm{H}$ was not observed at $3400 \mathrm{~cm}^{-1}$, suggesting that there is no water molecule in the $p d l$ complexes. However, the mechanism of the pdl complex formation has not been established. The $[\mathrm{Fe}(p d l)]\left[\mathrm{LiCr}\left(\mathrm{C}_{2} \mathrm{O}_{4}\right)_{3}\right]$ compound might be a polymeric complex with two oxalate ligands connecting three metal ions, and for the $\left[\mathrm{Fe}(p d \mathrm{l})_{2}\right]\left[\mathrm{LiCr}\left(\mathrm{C}_{2} \mathrm{O}_{4}\right)_{3}\right]$ compound only one oxalate ligand bridges the iron and chromium ions, leading to a bimetallic complex. The possible structures for the two $\left[\mathrm{Fe}(p d l)_{\mathrm{n}}\right]\left[\mathrm{LiCr}\left(\mathrm{C}_{2} \mathrm{O}_{4}\right)_{3}\right]$ compounds are illustrated in Figure 3. 


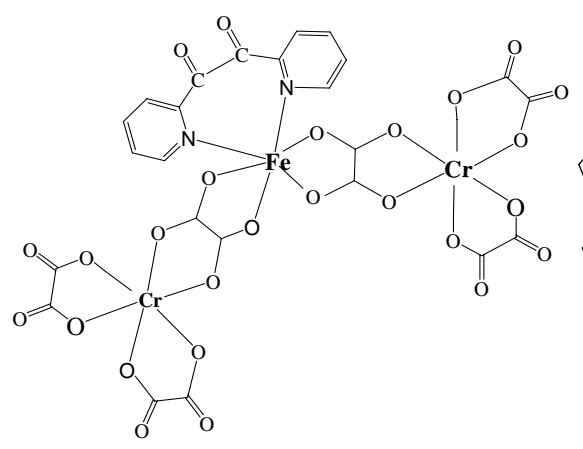

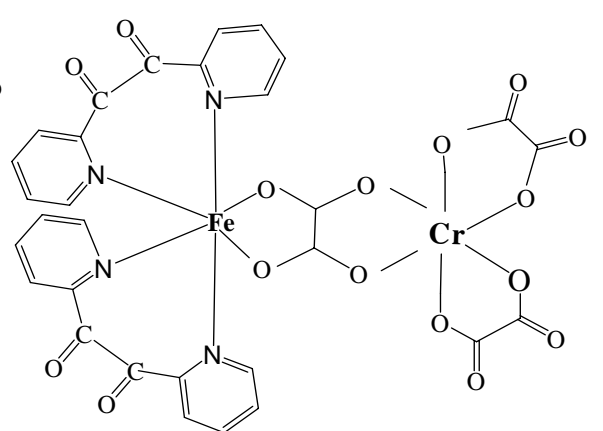

Figure 3 Possible structure of $\left[\mathrm{Fe}(p d l)_{\mathrm{n}}\right]\left[\mathrm{LiCr}\left(\mathrm{C}_{2} \mathrm{O}_{4}\right)_{3}\right]$ complexes.

\subsection{Magnetic Measurements}

The magnetic properties of a powdered sample of $\left\{\mathrm{Li}\left[\mathrm{FeCr}\left(\mathrm{C}_{2} \mathrm{O}_{4}\right)_{2}(p q)\left(\mathrm{BF}_{4}\right)_{2}\left(\mathrm{H}_{2} \mathrm{O}\right)_{2}\right]\right\}$ were measured at room temperature, the data collected has been given in Table 3.

Table 3 The magnetic data of $[\mathrm{Fe}(p q)]\left[\mathrm{LiCr}\left(\mathrm{C}_{2} \mathrm{O}_{4}\right)_{2}\left(\mathrm{BF}_{4}\right)_{2}\right] 2 \mathrm{H}_{2} \mathrm{O}$ compound.

\begin{tabular}{cccccc}
\hline \multicolumn{5}{c}{ The magnetic variable } & \multirow{2}{*}{$\mu_{\text {eff }}(\mathbf{B M})$} \\
\cline { 1 - 5 } $\mathbf{T}(\mathbf{K})$ & $\mathbf{m}(\mathbf{g})$ & $\mathbf{l}(\mathbf{C m})$ & $\mathbf{R o}$ & $\mathbf{R}$ & \\
\hline 297 & 0.1114 & 1.7 & -34 & 1076 & 5.7 \\
\hline
\end{tabular}

Each of the two metal ions on the multinuclear complex: $\mathrm{Cr}(\mathrm{III})$ and $\mathrm{Fe}(\mathrm{II})$ contribute to the magnetic properties of this complex. The spin-only magnetic moment $\left(\mu_{\mathrm{so}}\right)$ for $\mathrm{Cr}(\mathrm{III})\left([\mathrm{Ar}] 3 \mathrm{~d}^{3}\right)$ is $3.9 \mathrm{BM}$. While the values for $\mathrm{Fe}(\mathrm{II})$ ([Ar] $3 \mathrm{~d}^{6}$ ) is $0 \mathrm{BM}$ at a low spin state and $4.9 \mathrm{BM}$ at a high spin. Therefore, the spinonly magnetic moment for multinuclear Fe-Li-Cr complex is 3.9 BM for $\mathrm{Li}(\mathrm{I})$ $\mathrm{Cr}(\mathrm{III})-\mathrm{Fe}(\mathrm{II})$ in low spin state, and 6.3 $\mathrm{BM}$ for $\mathrm{Li}(\mathrm{I})-\mathrm{Cr}(\mathrm{III})-\mathrm{Fe}(\mathrm{II})$ in high spin state. The measured magnetic moment for $[\mathrm{Fe}(p q)]\left[\mathrm{LiCr}\left(\mathrm{C}_{2} \mathrm{O}_{4}\right)_{2}\left(\mathrm{BF}_{4}\right)_{2}\right] 2 \mathrm{H}_{2} \mathrm{O}$ at room temperature is $5.7 \mathrm{BM}$. This suggests that most of $\mathrm{Fe}(\mathrm{II})$ ion on the complex is in high spin state and only small fraction of the Fe(II) is in low spin state.

Similar results have been found for $\left[\mathrm{Fe}(p d l)_{\mathrm{n}}\right]\left[\mathrm{LiCr}\left(\mathrm{C}_{2} \mathrm{O}_{4}\right)_{3}\right]$. The measured magnetic moment values are found to be 4.8 BM for $n=1$ and $5.5 \mathrm{BM}$ for $\mathrm{n}=2$. This indicates that both high spin and low spin fractions of iron(II) exist in those compounds.

The magnetic properties of the two complexes above could not be compared with the magnetic properties for complex of parent 2,2'-bipyridine ligand, due to different chemical formulation observed. In the bipyridine derivatives only 
one and two ligand molecules involved in the multinuclear complex compounds, while for parent 2,2'-bipyridine multinuclear complex three ligand molecules are involved in coordination.

\section{Conclusions}

The multinuclear Fe-Li-Cr compounds have been synthesized, their chemical formula are $\left\{\mathrm{Li}\left[\mathrm{FeCr}\left(\mathrm{C}_{2} \mathrm{O}_{4}\right)_{2}(p q)\left(\mathrm{BF}_{4}\right)_{2}\left(\mathrm{H}_{2} \mathrm{O}\right)_{2}\right]\right\}$ and $\left[\mathrm{Fe}(p d l)_{n}\right]\left[\mathrm{LiCr}\left(\mathrm{C}_{2} \mathrm{O}_{4}\right)_{3}\right]$, with $\mathrm{n}=1$ and 2 . The formulas have been supported by metal ion contents and the elemental $\mathrm{C}, \mathrm{H} \& \mathrm{~N}$ data. The IR spectra in the range $350-4000 \mathrm{~cm}^{-1}$ suggests that the oxalate ion fuctions as a bridging ligand between the $\mathrm{Fe}(\mathrm{II})$ and $\operatorname{Cr}(\mathrm{III})$ metal ions, and also shows the existence of water molecules in the multinuclear $p q$ compounds. The structures of the complexes have been drawn to support the mechanism of the multinuclear complex formation. The magnetic measurement exhibits the fraction of both high and low spin states of iron(II) in all complexes.

\section{Acknowledgements}

This research is funded by ITB Research Grant No. 0076/K01.03/PL2.1.5/VI/2005. The authors are thankful to Prof. Ibrahim Baba(UKM) for C, H, N elemental data.

\section{References}

[1] Goodwin, H.A., Spin Transitions in Six-Coordinate Iron(II) Complexes, Coord. Chem. Rev., 18, 293, 1976.

[2] Gutlich, P. Garcia, \& Goodwin, H. A., Spin Crossover Phenomena in Fe(II) Complexes, Chem. Soc. Rev., 29, 419-427, 2000.

[3] Le’tard, J.F., Real, J.A., Moliner, N., Gaspar, A.B., Capes, L., Cador, O. \& Kahn, O., Light Induced Excited Pair Spin State in an Iron(II) Binuclear Spin-Crossover Compound, J. Am. Chem. Soc., 121, 1063010631, 1999.

[4] Real, J.A., Gaspar, A.B., Niel, V. \& Munoz, M.C., Communication Between Iron(II) Building Blocks in Cooperative Spin Transition Phenomena, Coord. Chem. Rev., 236, 121, 2003.

[5] Pellaux, R., Schmale, H.W., Huber, R., Fischer, P., Hauss, T., Ouladdiaf, B. \& Decurtins, S., Molecular Based Magnetism in Bimetallic Two Dimensional Oxalate Bridge Networks. An X-ray and Neutron Diffraction Study, Inorg. Chem., 36, 2301-2308, 1997.

[6] Sieber, R., Decurtins, S., Stoeckli, E., Wilson C, Capelli, S., Hauser, A., Thermal Spin Transition in $\left[\mathrm{Co}(\text { bpy })_{3}\right]\left[\mathrm{LiCr}(\mathrm{ox})_{3}\right]\left(\mathrm{ox}=\mathrm{C}_{2} \mathrm{O}_{4}{ }^{2-}\right.$; bpy $=$ 2,2'-bipyridine), Chem. Eur. J., 2, 361-368, 2000. 
70 Djulia O nggo, lis Siti J a hro, Fa himah Martak \& Ismunandar

[7] Harris, C.M., Kokot, S., Patil, H.R.H., Sinn, E. \& Wong, H., High- and Low-Spin Complexes with Similar Ligands: II. Iron (II) Complexes with Sterically Hindered Analogues of 2,2'-bipiridil, Aust. J. Chem., 25, 16311643, 1972.

[8] Jahro, I. S., Onggo, D., Ismunandar \& Rahayu, S. I., Studi Sifat Magnet Senyawa Polimer Kompleks $\left\{\left[\mathrm{N}\left(n-\mathrm{C}_{4} \mathrm{H}_{9}\right)_{4}\right]\left[\mathrm{MnCr}\left(\mathrm{C}_{2} \mathrm{O}_{4}\right)_{3}\right]\right\}$, Prosiding Seminar Nasional Kimia XIV, Jurusan Kimia FMIPA UGM, 180-187, 2005. 